Іванченко А. М. [1; ORCID ID: 0000-0002-1571-7173], к.е.н., доцент

${ }^{1}$ Національний університет водного господарства та природокористування, м. Рівне

\title{
АНАЛІЗ ДІЯЛЬНОСТІ БУДІВЕЛЬНИХ ПІДПРИЕМСТВ НА РИНКУ НЕРУХОМОСТІ УКРАЇНИ
}

У роботі проаналізовано основні аспекти діяльності будівельних підприємств з реалізації об'єктів житлової та комерційної нерухомості як складових ринку нерухомості. Розглянуто ризики кожного з основних факторів, що вплинули на будівництво: інвесторів, забудовників і тенденції самого ринку. Особливу увагу приділено недосконалості чинної нормативно-правової бази, яка регулює діяльність усіх учасників будівництва. Здійснено аналіз основних типових драйверів та перепон 3 реалізації об'єктів житлової та комерційної нерухомості.

Ключові слова: державний фонд регіонального розвитку; ризики будівництва; нерухомість; фінансування будівництва.

Останні роки стали періодом великих змін та потрясінь для економіки. Криза, спричинена коронавірусом, відобразилась у тому числі і на будівельній галузі, адже ця сфера дуже чутлива до економічних негараздів.

Значну увагу діяльності будівельних підприємств на ринку житлової та комерційної нерухомості у науковій літературі приділили Т. Коллер, Т. Коупленд, М. Міллер, Ф. Модільяні, Дж. Стюарт, К. Уолт, Дж. Фридман, Г. Харрісон, Дж. Хікс, У. Шарп та багато інших. Серед українських вчених можна виділити таких, як П.Круш, А.Гойко, О. Кузьмін, Я. Маркус, В. Панков та інші.

Початок минулого року відзначився спадом у всіх галузях народного господарства, у тому числі і в реалізації будівельних проектів. Через локдауни і закриття кордонів ланцюжки постачання порушились, роботи практично зупинялись, що відобразилось на глобальних тенденціях ринку нерухомості. Зокрема, у Євросоюзі станом на осінь падіння склало більше 4\%. I хоча влітку галузь почала відновлюватись, але так і не досягла свого докризового рівня.

Нова хвиля COVID-19 восени знову підкосила будівельників. Житлова нерухомість стала першою жертвою коронакризи. У США в 
2020 році, наприклад, звели багатоквартирних будинків на $12 \%$ менше ніж позаминулого. Зважаючи на це, архітекторам та забудовникам не відмовиш у сміливості, прагненні до інновацій та експериментаторстві.

Трендом залишалося зведення енергоефективних будинків. Через введення нових будівельних норм та забезпечення протикороновірусних вимог, до житлової і особливо комерційної нерухомості висувають нові вимоги щодо соціальної дистанції та вентиляції, а це безпосередньо вплине на енергетичну ємність споруд. Тому у подальшому будівельники будуть вирішувати цю проблему, а також змушені будуть рахуватися з тим фактом, що житло сьогодні - це місце роботи для людей, які перейшли у режим дистанційної праці.

Споживання енергії у житлових спорудах збільшилось на 20$30 \%$, що є потужним викликом для тих забудовників, які роблять ставку на енергоефективність.

Нові технології визначають майбутнє будівництва. Це контроль за будівельними майданчиками за допомогою дронів, 3D друк, технологія будівельно-інформаційного моделювання (ВIM). Вони значно зменшують вартість будівництва, зменшують терміни реалізації об'єктів нерухомості та підвищують екологічність споруд. Зокрема, у Німеччині в м. Беккум побудували перший в країні 3D житловий будинок. Аналогічні друковані споруди вже існують в OAE, Данії, Швеції, США, Мексиці та інших країнах. Експерти прогнозують, що технологія буде вдосконалюватись і ї̈ сфера застосування розшириться.

Трендом поступово стає декарбонізація будівництва. На будівельні об'єкти (спорудження та експлуатація) припадає 38\% викидів $\mathrm{CO}_{2}$ в атмосферу, що суттєво впливає на зміну клімату. Тому у 2020 році у світі багато більше приділяли уваги саме низьковуглецевому будівництві, тобто створенню такої нерухомості, яка б не генерувала парникові гази. І успішні кейси вже $\epsilon$.

Забудовники та проектувальники все частіше звертаються до так званої вуглецево-нейтральної архітектури. Ї̈ приклад - готель Bauhofstrasse у німецькому місті Людвігсбург, який у минулому році ввели в експлуатацію. Будівельники стверджують, що ця споруда створена без парникових викидів, оскільки у ній використані переважно дерев'яні конструкції. Аналогічно вуглецево-нейтральні споруди вже спроектовані і найближчим часом з'являться у Нідерландах, Фінляндії, Великобританії та Норвегії.

У 2020 році розвивалася так звана «зелена» архітектура, в якій 
зелені зони знаходяться не лише поруч з будинком, а є обов'язковою його частиною. Найбільшим таким реалізованим проєктом стали апартаменти EDEN від компанії Heatherwick Studio у Сінгапурі. Його творці виходили з концепції поєднання тропічного саду та сучасного комфортабельного житлового простору. Центральним елементом будівлі є стилізовані балкони, які заповнені тропічними рослинами.

Успішно крокує світом практика mixed use development поєднання житлового, комерційного та виробничого секторів на одному просторі. Яскравий приклад такого підходу - житловий район Bahnstadt у німецькому Гейдельберзі, де адміністративні споруди мирно сусідять з житлом. А також багатофункціональний комплекс Smile в Нью-Йорку, що поєднує 223 житлові приміщення 3 навчальними закладами.

Україна надто залежна від глобальних економічних змін і тому світова криза серйозно відображена на будівельній галузі зокрема. Свідченням цьому $€$ значне призупинення темпів будівництва як житла, так і об'єктів з використанням коштів Державного фонду регіонального розвитку у 2020 році.

Минулого року, згідно з розпорядженням КМУ № 211-р за пропозиціями обласних та Київської міської держадміністрацій, між проєктами та програмами було розподілено 4,7 млрд гривень Державного фонду регіонального розвитку (попередньо на фінансування ДФРР пропонували надати 9,4 млрд грн, але у підсумку відновили соціально-економічні субвенції та виділили на ДФРР лише 7,5 млрд грн).

У період урізання статей видатків для створення ковід-фонду у квітні 2020 року навколо ДФРР довго тривали дискусії. У першій версії змін до бюджету для цілей ковід-фонду ДФРР пропонували прибрати взагалі (всі 7,5 млрд), але зрештою розподілені на той час суми таки залишили Фонду. У підсумку, з ДФРР до ковід-фонду перейшов лише нерозподілений залишок - 2,74 млрд грн.

Розподіл за напрямами у 2020 не надто відрізнявся від цьогорічних пропорцій - найбільша частка на освіту, на другому місці проєкти пов'язані зі спортом, а третьоює медицина.

Фінансування видатків ДФРР у 2020 році було на рівні 89,7\% асигнувань було відкрито згідно з планом (4,87 млрд грн), а касові видатки досягли лише 4,37 млрд грн. Рівень виконання 3 кожним роком зростає.

Однак, у 2020 році ситуація із виконанням плану у різних областях була різною - найменше було профінансовано у Сумській області - лише 70,34\% від передбаченого обсягу, у Кіровоградській 
трохи більше - 73,22\%. Найвищий показник на Полтавщині - 98,92\% та Львівщині - 97,97\% (табл. 1).

Індекс будівельної продукції за січень-листопад минулого року у сегменті житлової нерухомості склав $82,6 \%$ у порівнянні 3 аналогічним періодом 2019 року. При цьому обсяги зведення комерційних об'єктів нерухомості майже не змінились (99,3\%), а будівництво інженерних споруд навіть випередило темпи 2019 року $(111,6 \%)$. Це наслідки реалізації державної програми «Велике будівництво», у межах якої відремонтували понад 3,9 тис. км автодоріг.

В Україні спад в будівництві відчувався особливо гостро, адже Київ $\epsilon$ традиційно флагманом галузі. У січні-вересні в експлуатацію ввели лише 59\% від площі об'єктів житлової нерухомості, які були зведені за цей же час у 2019 році. Лідерами появи нового житла стали Солом'янський та Голосіївський райони. А загальний обсяг нових забудов у Києві за січень-листопад склав 97\% у порівнянні 3 позаминулим роком. Як і в цілому по країні, найбільший провал відчувався у житловому сегменті (79\%).

На жаль, замість проривів та інновацій 2020 рік не став винятком в Україні, він був також врожайним і на будівельні скандали. Яскравий приклад цьому банкрутство банку «Аркада», сумнозвісна діяльність «Укрбуду» та «Рівненської брами», невдала реформа ДАБІ, а також сумнозвісний вибух житлового будинку на Позняках, що продемонстрував гостру потребу у кваліфікованих фахівцях та оновленні житлового фонду країни.

Таблиця 1

Використання коштів Державного фонду регіонального розвитку у 2020 році, тис. грн

\begin{tabular}{|c|c|c|c|c|c|}
\hline $\begin{array}{l}\text { № } \\
3 / \Pi\end{array}$ & Область & $\begin{array}{c}\text { Обсяг } \\
\text { фінансування, } \\
\text { передбачений } \\
\text { розпорядженням }\end{array}$ & $\begin{array}{c}\text { Спрямовано } \\
\text { асигнувань }\end{array}$ & $\begin{array}{l}\text { Касові } \\
\text { видатки }\end{array}$ & $\begin{array}{c}\text { \% вико- } \\
\text { нання }\end{array}$ \\
\hline 1 & 2 & 3 & 4 & 5 & 6 \\
\hline 1. & Вінницька & 143524,50 & 143524,50 & 138415,13 & $96,44 \%$ \\
\hline 2. & Волинська & 190294,71 & 190294,71 & 162624,81 & $85,46 \%$ \\
\hline 3. & $\begin{array}{l}\text { Дніпропетровсь- } \\
\text { ка }\end{array}$ & 292364,41 & 292364,41 & 240272,23 & $82,18 \%$ \\
\hline 4. & Донецька & 461695,41 & 461695,41 & 441507,58 & $95,63 \%$ \\
\hline 5. & Житомирська & 216823,73 & 216823,73 & 201951,03 & $93,14 \%$ \\
\hline 6. & Закарпатська & 184636,30 & 184636,30 & 169080,00 & $91,57 \%$ \\
\hline 7. & Запорізька & 157801,33 & 157801,33 & 143681,52 & $91,05 \%$ \\
\hline 8. & $\begin{array}{l}\text { Івано- } \\
\text { Франківська }\end{array}$ & 220350,85 & 220350,85 & 210958,18 & $95,74 \%$ \\
\hline
\end{tabular}


продовження табл. 1

\begin{tabular}{|c|l|l|l|l|l|}
\hline 9. & Київська & 166638,43 & 166638,43 & 145155,40 & $87,11 \%$ \\
\hline 10. & Кіровоградська & 87241,82 & 87241,82 & 63874,90 & $73,22 \%$ \\
\hline 11. & Луганська & 226796,92 & 226796,92 & 205456,88 & $90,59 \%$ \\
\hline 12. & Львівська & 235030,93 & 235030,93 & 230264,38 & $97,97 \%$ \\
\hline 13. & Миколаївська & 104751,10 & 104751,10 & 95758,56 & $91,42 \%$ \\
\hline 14. & Одеська & 219961,82 & 219961,82 & 191448,42 & $87,04 \%$ \\
\hline 15. & Полтавська & 129727,87 & 129727,87 & 128332,85 & $98,92 \%$ \\
\hline 16. & Рівненська & 186586,36 & 186586,36 & 176732,56 & $94,72 \%$ \\
\hline 17 & Сумська & 202236,93 & 202236,93 & 142252,90 & $70,34 \%$ \\
\hline 18. & Тернопільська & 174835,70 & 174835,70 & 150632,26 & $86,16 \%$ \\
\hline 19 & Харківська & 247674,31 & 247674,31 & 228164,31 & $92,12 \%$ \\
\hline 20. & Херсонська & 183703,35 & 183703,35 & 159173,48 & $86,65 \%$ \\
\hline 21. & Хмельницька & 216172,50 & 216172,50 & 204895,86 & $94,78 \%$ \\
\hline 22. & Черкаська & 111440,89 & 111440,89 & 96415,19 & $86,52 \%$ \\
\hline 23. & Чернівецька & 144976,65 & 144976,65 & 132714,68 & $91,54 \%$ \\
\hline 24. & Чернігівська & 92683,78 & 92683,78 & 89166,97 & $96,21 \%$ \\
\hline 25. & М. Київ & 274963,37 & 274963,37 & 221963,47 & $80,72 \%$ \\
\hline & Разом & 4872913,96 & 4872913,96 & 4370893,54 & $89,70 \%$ \\
\hline
\end{tabular}

Джерело: дані Державного фонду регіонального розвитку [9]

Попри усі негаразди, у вітчизняній будівельній галузі $€$ й позитивні зрушення. Так, набули чинності зміни до Порядку розробки проектної документації на будівництво об'єктів, які дозволяють використовувати сучасні інноваційні ВІМ-технології.

Зазначені вимоги відкривають перед проєктантами надзвичайно широкі можливості. З'являються проєкти, де реалізований у життя принцип mixed use development, все частіше використовуються енергоефективні технології, а деякі новобудови отримують сертифікацію за стандартами BREEAM, LEED та ActiveHouse, що поєднують екологічність, заощадження енергії та комфорт.

$€$ сподівання, що наступні постковідні роки, стануть переломним у будівельній галузі, а українські забудовники і проєктанти активніше перейматимуть прогресивні світові практики та підходи. Однак важливою передумовою такій тенденції $€$ саме конкуренція серед реалізованих проєктів та запит від потенційних покупців нерухомості, які мають вимагати високих стандартів житла. I в результаті матимемо більш комфортне міське середовище, а наші міста не лише не втратять свій естетичний вигляд, а й набудуть привабливості для туристів. Натомість будівельні скандали будуть у минулому, інвестиції у будівництво матимуть більш прогнозований та захищений характер, а на виході країна отримає якісні, сучасні та 
енергоефективні споруди, з низькими експлуатаційними витратами та споживанням енергії.

Пріоритетними напрямами будівельних підприємств є: поліпшення роботи будівельних підприємств за рахунок оновлення основних фондів; впровадження інноваційних будівельних технологій; підвищення якості будівельної продукції; вдосконалення управління, розширення горизонту планування і більш точний облік на вимоги ринку; розробка довгострокових програм з розширення можливостей фінансування будівництва державними i регіональними органами влади (ДФРР); сприяння розвитку будівельної галузі в цілому. Важливим напрямом у формуванні конкурентоспроможності української будівельної галузі, стабілізації і послідовному розвитку будівельного ринку в регіонах $€$ виявлення i стимулювання розвитку регіональних будівельних утворень. Особливістю підприємств будівельної галузі $€$ те, що вони дуже чутливі до факторів макроекономічного середовища. Ось чому головним завданням забезпечення ефективності будівництва загалом є мінімізація негативного впливу зовнішнього середовища за допомогою стратегічного управління. Для збільшення обсягів виконання будівельно-монтажних робіт, слід дотримуватись таких принципів, як максимальне використання місцевих видів будівельних матеріалів, контроль за діяльністю замовників і обґрунтування кошторисної вартості об'єктів, що будуються, зведення до мінімуму кількості будівельних об'єктів, що одночасно реалізовуються. Тому будівельні підприємства повинні об'єктивно визначати свою конкурентну позицію, виявляти основні зовнішні чинники, що впливають на обсяги виробництва, і створювати нові конкурентні переваги. Вийти з кризового стану можливо лише за допомогою поєднання ефективних державних регулюючих економічних інструментів та стратегічно сформованої програми діяльності будівельних підприємств.

1. Адамська І. Сучасний стан й тенденції розвитку будівельної галузі України. Галицький економічний вісник. 2019. № 5. С. 7-15. 2. Будівельна галузь у 2019 році. URL: $\quad$ https://www.rbc.ua/ukr/news/stroitelnaya-otrasl-2019-godupokazala rekordnyy-1579790957.html. (дата звернення: 18.03.2021). 3. Головна аналітика введеного в експлуатацію житла. URL: http://budport.com.ua/news/12888-golovna-analitikałvvedenogo-v-ekspluataciyuzhitla-za-rik-vvedeno-na-57-menshe. (дата звернення: 18.03.2021). 4. Обсяги будівництва та виробництва будівельних матеріалів в Україні: реальна ситуація. URL: $\quad$ http://budport.com.ua/news/15423-obsyagi-budivnictva-ta-virobnictvabudivelnih-materialiv-v-ukrajni-realna-situaciya. (дата звернення: 18.03.2021). 5. Оскома О., Колосова А., Засікан К. Аналіз стану та тенденції розвитку будівельної 70 
галузі України. Глобальні та національні проблеми економіки. 2015. № 8. С. 551-554. 6. Методичні рекомендації щодо відслідковування динаміки основних економічних показників роботи стратегічно важливих підприємств і підприємств-монополістів (на основі індивідуального моніторингу підприємств). URL: http://www.me.gov.ua/Documents/List?lang=ukUA\&tag=MetodichniRekomendatsii\&p ageNumber=4. (дата звернення: 18.03.2021). 7.ДСТУ Б Д.1.1-1:2013. Правила визначення вартості будівництва. URL: http://dbn.at.ua/ load/normativy/dstu/dstu_b_d_1_1_1_2013/5-1-0-1113. (дата звернення: 18.03.2021). 8. Рогожин П. Економіка будівельних організацій. К. : Скарби, 2011. 448 с. 9. Офіційний сайт Державного комітету статистики України. Оперативна статистична інформація. URL: http: // www.ukrstat.gov.ua (дата звернення: 18.03.2021).

\section{REFERENCES:}

1. Adamska I. Suchasnyi stan y tendentsii rozvytku budivelnoi haluzi Ukrainy. Halytskyi ekonomichnyi visnyk. 2019. № 5. S. 7-15. 2. Budivelna haluz u 2019 rotsi. URL: https://www.rbc.ua/ukr/news/stroitelnaya-otrasl-2019-godu-pokazala rekordnyy1579790957.html. (data zvernennia: 18.03.2021). 3. Holovna analityka vvedenoho v ekspluatatsiiu zhytla. URL: http://budport.com.ua/news/12888-golovna-analitika vvedenogo-v-ekspluataciyu-zhitla-za-rik-vvedeno-na-57-menshe. (data zvernennia: 18.03.2021). 4. Obsiahy budivnytstva ta vyrobnytstva budivelnykh materialiv $v$ Ukraini: realna sytuatsiia. URL: http://budport.com.ua/news/15423-obsyagi-budivnictva-tavirobnictva-budivelnih-materialiv-v-ukrajni-realna-situaciya. (data zvernennia: 18.03.2021). 5. Oskoma O., Kolosova A., Zasikan K. Analiz stanu ta tendentsii rozvytku budivelnoi haluzi Ukrainy. Hlobalni ta natsionalni problemy ekonomiky. 2015. № 8. S. 551-554. 6. Metodychni rekomendatsii shchodo vidslidkovuvannia dynamiky osnovnykh ekonomichnykh pokaznykiv roboty stratehichno vazhlyvykh pidpryiemstv $i$ pidpryiemstv-monopolistiv (na osnovi indyvidualnoho monitorynhu pidpryiemstv). URL: http://www.me.gov.ua/Documents/List?lang=ukUA\&tag=MetodichniRekomendatsii\&p ageNumber=4. (data zvernennia: 18.03.2021). 7. DSTU B D.1.1-1:2013. Pravyla vyznachennia vartosti budivnytstva. URL: http://dbn.at.ua/ load/normativy/dstu/dstu_b_d_1_1_1_2013/5-1-0-1113. (data zvernennia: 18.03.2021). 8. Rohozhyn P. Ekonomika budivelnykh orhanizatsii. K. : Skarby, 2011. 448 s. 9. Ofitsiinyi sait Derzhavnoho komitetu statystyky Ukrainy. Operatyvna statystychna informatsiia. URL: http: // www.ukrstat.gov.ua (data zvernennia: 18.03.2021). 


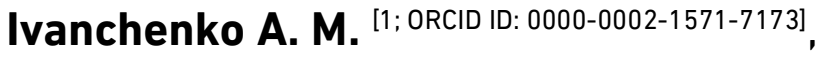
Candidate of Economics (Ph.D.), Associate Professor

${ }^{1}$ National University of Water and Environmental Engineering, Rivne

\section{ANALYSIS OF THE ACTIVITY OF CONSTRUCTION ENTERPRISES IN THE REAL ESTATE MARKET OF UKRAINE}

The paper analyzes the main aspects of construction companies for the sale of residential and commercial real estate as components of the real estate market. The risks of each of the main factors that influenced the construction are considered: investors, developers and market trends. Particular attention is paid to the imperfections of the current legal framework governing the activities of all participants in construction. An analysis of the grouping of the main typical drivers and barriers to the sale of residential and commercial real estate.

An important direction in the formation of the competitiveness of the Ukrainian construction industry, stabilization and consistent development of the construction market in the regions is to identify and stimulate the development of regional construction companies. The peculiarity of construction companies is that they are very sensitive to macroeconomic factors. That is why the main task of ensuring the efficiency of construction in general is to minimize the negative impact of the external environment through strategic management. To increase the volume of construction and installation work, the following principles should be followed: maximum use of local types of construction materials, control over the activities of customers and justification of the estimated cost of facilities under construction, minimizing the number of construction projects sold simultaneously. Therefore, construction companies must objectively determine their competitive position, identify the main external factors that affect production, and create new competitive advantages.

Keywords: state fund of regional development; construction risks; real estate; construction financing.

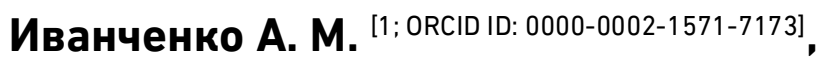

к.э.н., доцент

${ }^{1}$ Национальный университет водного хозяйства и природопользования, г. Ровно

\section{АНАЛИЗ ДЕЯТЕЛЬНОСТИ СТРОИТЕЛЬНЫХ ПРЕДПРИЯТИЙ НА РЫНКЕ НЕДВИЖИМОСТИ УКРАИНЫ}

\footnotetext{
В работе проанализированы основные аспекты деятельности строительных предприятий по реализации объектов жилищной и
} 
коммерческой недвижимости, как составляющих рынка недвижимости. Рассмотрены риски каждого из основных факторов, которые влияют на строительство: инвесторов, застройщиков и тенденции самого рынка. Особенное внимание уделено несовершенной действующей нормативноправовой базы, которая регулирует деятельность всех участников строительства. Выполнен анализ основных типовых драйверов и преграды по реализации объектов жилищной и коммерческой недвижимости.

Ключевые слова: государственный фонд регионального развития; риски строительства; недвижимость; финансирование строительства.

Отримано: 20 березня $2021 \mathrm{p.}$ Прорецензовано: 25 березня 2021 р. Прийнято до друку: 26 березня 2021 р. 